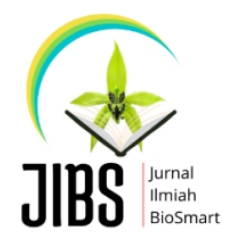

JURNAL ILMIAH BIOSMART (JIBS)

Volume 1, Nomor 1

https://jurnal.fkip.unmul.ac.id/index.php/biosmart

\title{
ANALISIS KUALITAS AIR DI PERAIRAN KELURAHAN SUNGAI PINANG LUAR DITINJAU DARI PENYEBARAN PLANKTON SEBAGAI BIOINDIKATOR
}

\author{
Mariani ${ }^{{ }^{*}}$, Masitah ${ }^{1}$ dan Herliani ${ }^{1}$ \\ Program Studi Pendidikan Biologi FKIP Universitas Mulawarman, Samarinda, Indonesia \\ Marianiiog9@gmail.com
}

\begin{abstract}
This study aims to determine the quality of water sources in the Kelurahan Sungai Pinang Luar Kota Samarinda based on the distribution of plankton and in accordance with the quality standards of mumus coral river water. The quality of river water is influenced by river flow velocity and various activities along the riverbanks. The levels of BOD and COD in rivers are an indicator of the presence of sources of organic pollutants such as from agriculture and domestic waste. This research was conducted for 1 month, this study used a purposive sampling method, namely the determination of the location based on the existence of certain objectives by the researcher and according to the researchers' own considerations so as to represent the population in the area. The composition of phytoplankton found during the study was dominated by the class Bacillariaophyceae and Cyanophyceae found in almost every observation station. The value of the phytoplankton diversity index ( $\left.\mathrm{H}^{\prime}\right)$ was 1.42 (medium category). The diversity index value $\left(\mathrm{H}^{\prime}\right)$ of zooplankton was 1.32 (medium category). From the results of the average plankton diversity found, which means the stability of the biota community is moderate and the quality of water is moderate.
\end{abstract}

Key word: Plankton, Water Quality Standard, Samarinda

\begin{abstract}
Abstrak Penelitian ini bertujuan untuk kualitas sumber air di Perairan Kelurahan Sungai Pinang Luar Kota Samarinda berdasarkan penyebaran plankton dan sesuai dengan baku mutu air sungai karang mumus. Kualitas air sungai dipengaruhi kecepatan aliran sungai dan bermacam aktivitas di bantaran sungai. Kadar BOD, COD di sungai merupakan indikator adanya sumber pencemar organik seperti dari pertanian dan limbah domestik. Penelitian ini dilaksanakan selama 1 bulan, penelitian ini menggunakan metode purposive sampling yaitu penentuan lokasi berdasarkan atas adanya tujuan tertentu oleh peneliti dan sesuai dengan pertimbangan peneliti sendiri sehingga mewakili populasi di daerah tersebut. Komposisi fitoplankton yang ditemukan selama penelitian di dominasi dari kelas Bacillariaophyceae dan Cyanophyceae ditemukan hampir disetiap stasiun pengamatan. Nilai indeks keanekaragaman ( $H^{\prime}$ ) fitoplankton 1,42 (kategori sedang). Nilai indeks keanekaragaman (H') zooplankton 1,32 (kategori sedang). Dari hasil rata-rata keanekaragaman plankton yang ditemukan yang artinya distabilitas komunitas biota sedang dan kualitas air tercemar sedang.
\end{abstract}

Kata Kunci: Plankton, Baku Mutu air, Samarinda

Penerbit

Program Studi Pendidikan Biologi, Fakultas Keguruan dan Ilmu Pendidikan, Universitas Mulawarman, Samarinda, Kalimantan Timur, Indonesia 


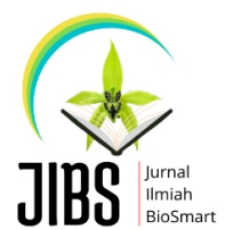

JURNAL ILMIAH BIOSMART (JIBS)

Volume 1, Nomor 1

https://jurnal.fkip.unmul.ac.id/index.php/biosmart

\section{PENDAHULUAN}

Kota Samarinda merupakan ibu kota Provinsi Kalimantan Timur kota tepian sungai, tidak lepas dari keberadaan sungai-sungai besar (DAS Sungai Mahakam dan Sub DAS karang Mumus) yang membelah wilayah samarinda menjadi dua bagian yaitu Samarinda Seberang dan Samarinda Kota. Keadaan morfologi Kota Samarinda sangat sensitif untuk dikembangan, wilayah bagian utara merupakan daerah bergelombang dan juga merupakan daerah resapan air sedangkan untuk wilayah bagian selatan cenderung berbukit dan banyak terdapat daerah patahan. Oleh karena itu, tidak mudah untuk menetapkan daerah-daerah yang layak. Sesuai kondisi forfologi yang demikian, maka sistem resapan air berdasarkan pola aliran air tanah (run off) mengalami hambatan dan umumnya mengalir menepati daerah tangkapan air (catchment area) berupa cekungan pada dataran-dataran rendah (rawa) yang kemudian secara alami mengalir ke outlet DAS Mahakam yang berada di tengah kota Samarinda (Warsilan, 2018: 70-71).

Seiring dengan perkembangan kota, maka sebagian besar kawasan hulu dari Sub DAS Karangmumus telah mengalami tekanan degredasi terutama akibat pembalakan, peningkatan kebutuhan lahan untuk permukiman, dan perubahan lahan untuk permukiman, dan perubahan fungsi kawasan. Kondisi tersebut sangat nyata terlihat pada kawasan rawa-rawa bantaran yang membentang di sepanjang sungai Karang mumus Hilir dan bagian hilir anak sungai-sungai lain, sebagian besar telah berubah menjadi kawasan ekonomi dan permukiman Dampak langsung yang dirasakan adalah terjadinya perubaham kesetimbangan air di Sub DAS Karangmumus yang terwujud dengan kejadian kekeringan dan banjir yang semakin meluas dan semakin kering mendera berbagai aspek kehidupan.

Undang-undang Republik Indonesia Nomor 23 Tahun 1997 tentang sektor industri atau usaha industri pangan dapat mencemari lingkungan antara lain tahu, tempe, tapioka dan pengolahan ikan. Limbah usaha kecil pangan dapat menimbulkan masalah dalam penangannya karena mengandung sejumlah besar karbohidrat, protein, lemak, garam- 


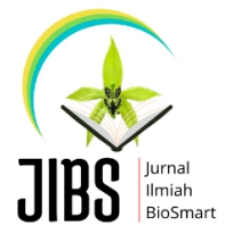

JURNAL ILMIAH BIOSMART (JIBS)

Volume 1, Nomor 1

https://jurnal.fkip.unmul.ac.id/index.php/biosmart

garam, mineral dan sisa bahan kimia yang digunakan dalam pengolahan dan pembersihan.

Di daerah Samarinda, tepatnya di Kelurahan Sungai Pinang Luar terdapat sungai karang mumus bagian Hilir anak sungai yang mengalir pada area pemukiman penduduk dan area pabrik tempe tahu. Secara umum kegiatan pembuatan tahu tersebut menyebabkan adanya limbah pada aliran sungai, sehingga mempengaruhi tingkat keasaman sungai karena akan meningkat dan pada akhirnya akan mengganggu kehidupan biota air. Air sungai karang mumus pada Kelurahan Sungai Pinang Luar dimanfaatkan oleh masyarakat untuk kehidupan sehari-hari seperti mandi, dan mencuci. Selain itu, pada lokasi sungai lainnya di gunakan untuk mencari ikan. Kualitas dan kuantitas sungai harus tetap terjaga untuk pemenuhan kebutuhan masyarakat didaerah Kelurahan Sungai Pinang Luar.

Organisme perairan dapat digunakan sebagai indikator pencemaran karena habitat, mobilitas dan umurnya yang relatif lama mendiami suatu wilayah perairan, sehingga indikator biologi ini dapat memantau secara kontinyu dan merupakan petunjuk yang mudah untuk memantau terjadinya pencemaran. Keberadaan plankton di perairan dapat dijadikan sebagai salah satu indikator suatu perairan karena sangat dipengaruhi oleh kualitas air.

Didalam sungai hidup bermacam-macam plankton yang semuanya mempunyai manfaat. Plankton adalah organisme yang berukuran kecil yang hidupnya terbawa oleh arus. Plankton terdiri dari zooplankton dan fitoplankton. Fitoplankton merupakan mikroorganisme yang berperan sebagai pengendali kualitas air dengan cara menyerap hasil metabolisme dan sisa pakan sebagai sumber energi (Junda, 2012: 109).

Sedangkan zooplankton bersifat heterotrofik, merupakan biota yang sangat penting peranannya dalam rantai makanan pada suatu ekosistem. Selain itu zooplankton juga berguna dalam regenerasi nitrogen di lautan dengan proses penguraiannya sehingga berguna bagi bakteri dan produktivitas fitoplankton di perairan (Ernawaty, 2011: 35). 


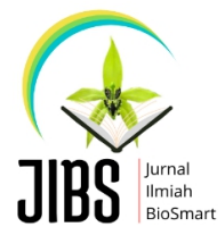

JURNAL ILMIAH BIOSMART (JIBS)

Volume 1, Nomor 1

https://jurnal.fkip.unmul.ac.id/index.php/biosmart

Aktifitas manusia dapat pula mengakibatkan dampak negatif seperti pencemaran terhadap lingkungan. Seperti pencemaran air yang terjadi di Kelurahan Sungai Pinang Ilir. Ditengah-tengah penduduk berdiri industri tahu yang sisa limbah cair industrinya di buang ke sungai aliran Mahakam sehingga mengakibatkan pencemaran air disekitar lingkungan tersebut. Dengan memperhatikan pentingnya keberadaan perairan karang mumus Samarinda ini sebagai rumah bagi keanekaragaman hayati yang hidup di dalamnya, maka sudah selayaknya kita perlu memperhatikan bagaimana kondisi perairan di Kelurahan Sungai Pinang Luar Kota Samarinda.

\section{METODE}

Penelitian ini termasuk dalam jenis penelitian deskriptif. Penelitian deksriptif yaitu penelitian dengan pengambilan data yang ada pada saat penelitian tanpa memberikan perlakuan terlebih dahulu. Penelitian deskriptif bertujuan untuk menggambarkan sesuatu, dalam penelitian ini yaitu untuk mengetahui kualitas air di Kelurahan Sungai Pinang Luar dan penyebaran plankton sebagai bionindikatornya. Jenis Penelitian yang dilakukan adalah bersifat deskriptif ubservasional dengan menggunakan metode purposive sampling. Metode purposive sampling yaitu penentuan lokasi berdasarkan atas adanya tujuan tertentu oleh peneliti dan sesuai dengan pertimbangan peneliti sendiri sehingga mewakili populasi di daerah tersebut.

\section{Alat dan Bahan}

Alat yang digunakan dalam penelitian ini adalah Plankton net, Botol Sampel, DO meter, pH meter, Pipet tetes, Mikroskop cahaya, GPS (Global Positioning System), Spektofotometer, Kertas saring, dan Ice box. Bahan yang digunakan dalam penelitian ini adalah air Sungai Karang Mumus dan cairan Lugol solution yang digunakan sebagai bahan pengawetan sampel plankton.

\section{Prosedur Penelitian}

1. Pengambilan data parameter biologi, kimia, dan fisika 


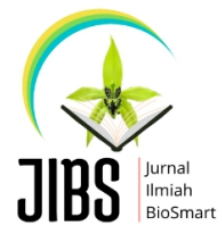

JURNAL ILMIAH BIOSMART (JIBS)

Volume 1, Nomor 1

https://jurnal.fkip.unmul.ac.id/index.php/biosmart

a. parameter Biologi

Pengambilan data biologi dengan cara mengambil sampel air laut pada masingmasing stasiun pengamatan. Pengambilan sampel air sungai dilakukan pada bagian permukaan sebanyak 5 liter yang selanjutnya disaring menggunakan plankton net. Hasil saringan yang berupa pemekatan dari 5 liter air yaitu sebanyak $5 \mathrm{ml}$ yang selanjutnya dituang ke dalam botol sampel. Setelah dituangkan, sampel tersebut ditetesi larutan lugol yang bertujuan untuk mengawetkan plankton tanpa harus merusak jaringannya. Botol sampel kemudian diberi label dan disimpan yang selanjutnya di analisis menggunakan mikroskop cahaya di Laboratorium Kualitas Air Fakultas Perikanan dan Ilmu Kelautan Universitas Mulawarman.

b. Parameter Kimia

Parameter kimia yang akan diukur adalah derajat keasaman $(\mathrm{pH})$, Biochemical Oxygen Demand (BOD), DO dan Chemical Oxygen Deman (COD)

1) Pengukuran derajat keasaman $(\mathrm{pH})$

Sampel air diambil pada permukaan perairan dengan menggunakan derijen ukuran 5 liter, kemudian sampel air di bawa ke laboratorium untuk di uji kandungan $\mathrm{pH}$ dengan menggunakan alat $\mathrm{pH}$ meter

2) Pengukuran Biochemical Oxygen Demand (BOD)

Sampel diberi larutan pengencer jenis oksigen yang juga telah ditambahkan larutan nutrisi dan bibit mikroba dan diinkubasi selama 5 hari pada suhu sekitar $20^{\circ} \mathrm{C}$ dalam ruangan gelap.

3) Pengukuran Chemical Oxygen Demand (COD)

Sampel dibawa ke laboratorium untuk diuji kandungan COD menggunakan Hach Programme dari spektrofotometer.

4) Pengukuran DO

Sampel di beri larutan jenis oksigen kemudian setelah melalui beberapa tahap dihitungan data yang telah dihasilkan.

c. Parameter Fisika 


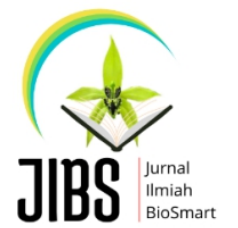

JURNAL ILMIAH BIOSMART (JIBS)

Volume 1, Nomor 1

https://jurnal.fkip.unmul.ac.id/index.php/biosmart

Parameter fisika yang diamati adalah suhu, dan Total Suspended Solid (TSS)

1) Pengukuran suhu

Pengukuran suhu dilakukan dengan menggunakan alat thermometer. Alat tersebut dicelupkan kedalam air sungai dan di diamkan sampai thermometer menunjukkan pada nilai yang konstan kemudian dicatat hasil pengukuran suhu.

2) Pengukuran Total Suspended Solid (TSS)

Padatan tersuspensi merupakan tempat berlangsungnya reaksi kimia yang heterogen dan berfungsi sebagai bahan pembentuk dari endapan sedimen yang paling awal dan TSS merupakan salah satu parameter yang digunakan untuk pengukuran kualitas air. Pengukuran dilakukan di Laboratorium dengan tahapan yaitu: ambil kertas saring wokmen no 41 lalu open selama 1 jam dengan suhu $103-105^{\circ} \mathrm{C}$, timbang kertas saring yang telah di open, saring sampel air sebanyak $100 \mathrm{ml}$, hasil saringan yang berupa kertas saring ditambah endapan diopen dengan suhu $103-105^{\circ} \mathrm{C}$ selama 3 jam, dinginkan dalam desikator untuk menyeimbangkan suhu dan timbang hasil open.

\section{HASIL PENELITIAN}

\section{A. Gambaran Umum Lokasi Penelitian}

Kelurahan Sungai Pinang Luar Kecamatan Samarinda Kota merupakan daerah yang batas wilayah pada bagian utaranya yaitu Sungai Karang Mumus dan bagian Selatannya berhadapan dengan Sungai Mahakam. Kelurahan Sungai Pinang Luar merupakan daerah yang terkena dampak pembuangan limbah cair industri tahu oleh karena adanya limbah cair industri tahu langsung dialirkan ke sungai atau selokan disekitar lokasi industri tahu. Selain itu juga terkena dampak limbah masyarakat yang bertempat tinggal di daerah itu sendiri. Akibat yang ditimbulkan yaitu tercemarnya air Sungai Karang Mumus yang banyak di manfaatkan oleh masyarakat untuk memenuhi kebutuhan sehari-hari, seperti mandi, mencuci dan lain-lain. 
JURNAL ILMIAH BIOSMART (JIBS)

Volume 1, Nomor 1

$\mathrm{JIBS}$

https://jurnal.fkip.unmul.ac.id/index.php/biosmart

Gambaran umum tentang Kelurahan Sungai Pinang Luar Kecamatan Samarinda Kota akan diuraikan dalam penelitian ini, yang mencakup letak dan luas daerah penelitian, kondisi geografis, letak administrasi, penggunaan lahan, dan kondsi sosial penuduk.

Penelitian ini dilakukan pada 3 titik stasiun, yaitu stasiun 1 berada di gang 7D berlokasi disekitar permukiman warga yang berada diatas air jika air sungai naik dengan kondisi yang cukup ramai dan padat. Stasiun 2 berada di gang 6D pada lokasi ini terdapat kawasan warga dan juga terletak dengan peternak ayam yang sangat dekat dengan sungai. Kemudian pada stasiun 3 berada di gang 4D pada lokasi disekitar industri atau pabrik tahu.

Berdasarkan hasin pengukuran kualitas air di Perairan Kelurahan Sungai Pinang Luar dapat disajikan dalam tabel dibawah ini.

Tabel. 1 Data Parameter Fisika di Perairan Kelurahan Sungai Pinang Luar

\begin{tabular}{|c|c|c|c|c|c|c|c|c|}
\hline \multirow[t]{2}{*}{ No } & \multirow{2}{*}{$\begin{array}{l}\text { Para } \\
\text { meter }\end{array}$} & \multirow{2}{*}{$\begin{array}{c}\text { Stasiu } \\
\mathrm{n}\end{array}$} & \multicolumn{3}{|c|}{ Hasil } & \multirow[t]{2}{*}{ Rata-rata } & \multirow[t]{2}{*}{$\mathrm{BM}$} & \multirow[t]{2}{*}{ Keterangan } \\
\hline & & & D1 & $\mathrm{D} 2$ & D3 & & & \\
\hline \multirow{3}{*}{1.} & \multirow{3}{*}{$\begin{array}{l}\text { Suhu } \\
\text { Air } \\
\left({ }^{\circ} \mathrm{C}\right)\end{array}$} & 1 & $29^{\circ} \mathrm{C}$ & $29^{\circ} \mathrm{C}$ & $29^{\circ} \mathrm{C}$ & $29^{\circ} \mathrm{C}$ & \multirow{3}{*}{ Devisiasi 3} & \multirow{3}{*}{$\begin{array}{l}\text { Memenuhi } \\
\text { Devisiasi } 3\end{array}$} \\
\hline & & 2 & $30^{\circ} \mathrm{C}$ & $28^{\circ} \mathrm{C}$ & $28^{\circ} \mathrm{C}$ & $28^{\circ} \mathrm{C}$ & & \\
\hline & & 3 & $30^{\circ} \mathrm{C}$ & $30^{\circ} \mathrm{C}$ & $30^{\circ} \mathrm{C}$ & $30^{\circ} \mathrm{C}$ & & \\
\hline \multirow{3}{*}{2.} & \multirow{3}{*}{$\begin{array}{c}\text { TSS } \\
(\mathrm{mg} / \\
\mathrm{L})\end{array}$} & 1 & 45 & 39 & 50 & 45 & 50 & Memenuhi kelas II \\
\hline & & 2 & 26 & 41 & 108 & 45 & 50 & Memenuhi kelas II \\
\hline & & 3 & 32 & 38 & 93 & 54 & 50 & $\begin{array}{c}\text { Tidak Memenuhi } \\
\text { kelas II }\end{array}$ \\
\hline
\end{tabular}

Keterangan:

*: Melebihi baku mutu air kelas 2

BM : Baku Mutu Air Kelas II (Peraturan Pemerintah No. 82 Tahun 2001)

Tabel 2. Data Parameter Kimia di Perairan Kelurahan Sungai Pinang Luar

\begin{tabular}{|c|c|c|c|c|c|c|c|c|}
\hline \multirow[t]{2}{*}{ No. } & \multirow{2}{*}{$\begin{array}{c}\text { Parame } \\
\text { ter }\end{array}$} & \multirow[t]{2}{*}{ Stasiun } & \multicolumn{3}{|c|}{ Hasil } & \multirow{2}{*}{$\begin{array}{l}\text { Rata- } \\
\text { rata }\end{array}$} & \multirow[t]{2}{*}{$\mathrm{BM}$} & \multirow[t]{2}{*}{ Keterangan } \\
\hline & & & D1 & D2 & D3 & & & \\
\hline \multirow[t]{3}{*}{1.} & \multirow[t]{3}{*}{$\mathrm{pH}$} & 1 & 6,62 & 6,64 & 6,63 & 6,63 & \multirow[t]{3}{*}{6} & \multirow[t]{3}{*}{ Memenuhi Kelas I } \\
\hline & & 2 & 6,52 & 6,59 & 6,55 & 6,55 & & \\
\hline & & 3 & 6,41 & 6,44 & 6,45 & 6,43 & & \\
\hline \multirow[t]{2}{*}{2.} & \multirow{2}{*}{$\begin{array}{c}\text { DO } \\
(\mathrm{mg} / \mathrm{L})\end{array}$} & 1 & 3,91 & 4,91 & 4,30 & 4,37 & 4 & Memenuhi kelas II \\
\hline & & 2 & 1,84 & 1,28 & 2,24 & 1,78 & 4 & Tidak memenuhi kelas II \\
\hline
\end{tabular}


JURNAL ILMIAH BIOSMART (JIBS)

Volume 1, Nomor 1

$\mathrm{JIBS}$

https://jurnal.fkip.unmul.ac.id/index.php/biosmart

\begin{tabular}{|c|c|c|c|c|c|c|c|c|}
\hline & & 3 & 1,84 & 1,52 & 1,44 & 0,98 & 4 & Tidak memenuhi kelas II \\
\hline 3. & BOD $_{5}$ & 1 & 2,76 & 2,99 & 4,21 & 3,32 & 3 & Memenuhi kelas II \\
\cline { 3 - 9 } & $(\mathrm{mg} / \mathrm{L})$ & 2 & 1,2 & 0,16 & 1,44 & 0,93 & $3^{*}$ & Tidak memenuhi kelas II \\
\cline { 3 - 9 } & & 3 & 0,48 & 0,96 & 0,8 & 0,74 & $3^{*}$ & Tidak memenuhi kelas II \\
\hline \multirow{2}{*}{4.} & $\begin{array}{c}\mathrm{COD} \\
(\mathrm{mg} / \mathrm{L})\end{array}$ & 1 & $\begin{array}{c}105,20 \\
4\end{array}$ & 76,590 & 77,120 & 86,304 & $25^{*}$ & Tidak Memenuhi kelas II \\
\cline { 3 - 9 } & & 2 & 95,666 & 81,889 & 88,778 & 86,777 & $25^{*}$ & Tidak Memenuhi kelas II \\
\cline { 3 - 9 } & & 3 & 62,283 & 62,813 & 77,120 & 67,405 & $25^{*}$ & Tidak Memenuhi kelas II \\
\hline
\end{tabular}

Keterangan:

*: Melebihi baku mutu air kelas 2

BM: Baku Mutu Air Sungai Kelas II (Peraturan Pemerintah No. 82 Tahun 2001)

Tabel 3. Keanekaragaman Plankton di Perairan Kelurahan Sungai Pinang Luar Kota Samarinda

\begin{tabular}{|c|c|c|c|c|c|c|}
\hline \multirow{2}{*}{ Jenis } & Kelas & Genus & Stasiun 1 & $\begin{array}{c}\text { Stasiun } \\
2\end{array}$ & $\begin{array}{c}\text { Stasiu } \\
\mathrm{n} 3\end{array}$ & $\begin{array}{c}\text { Jumla } \\
\mathrm{h}\end{array}$ \\
\hline Fitoplankton & Bacillariophyta & Tabellaria & 22 & 15 & 13 & 50 \\
\cline { 2 - 7 } & Ulvophyceae & Ulothrix & 13 & - & - & 13 \\
\cline { 2 - 7 } & Cyanophyceae & Oscillatoria & 14 & 11 & 12 & 37 \\
\cline { 2 - 7 } & Dinophyceae & Spirulina & - & - & 1 & 1 \\
\cline { 2 - 7 } & Zygnematophyceae & Closterium & 2 & 1 & - & 3 \\
\cline { 2 - 7 } & Bacillariphyceae & Naviculla & 2 & 3 & - & 5 \\
\cline { 2 - 7 } & & Surirella & - & - & 3 & 3 \\
\cline { 2 - 7 } & Chlorophyceae & Chlamydomona & - & - & 2 & 2 \\
\hline Zooplankton & Euglenapceae & Phacus & 8 & 3 & 2 & 13 \\
\cline { 2 - 7 } & & Trachelomonas & 4 & 1 & 1 & 6 \\
\cline { 2 - 7 } & Pytomastigophorea & Euglena & 8 & 7 & 8 & 23 \\
\cline { 2 - 7 } & Hydraulea & Arcella & 20 & 22 & 19 & 61 \\
\cline { 2 - 7 } & Rotifera & Filinia & 8 & - & - & 8 \\
\cline { 2 - 7 } & Loboseae & Centropxis & - & - & 5 & 5 \\
\hline
\end{tabular}

Tabel 4. Indeks Keanekaragaman, Keseragaman, Dominansi Fitoplankton di Kelurahan Sungai Pinang Luar Kota Samarinda

\begin{tabular}{|l|l|c|c|c|}
\hline No & Stasiun Penelitian & $\begin{array}{c}\text { Indeks } \\
\text { Keanekaragaman } \\
\left(\mathrm{H}^{\prime}\right)\end{array}$ & $\begin{array}{c}\text { Indeks } \\
\text { Keseragaman (E) }\end{array}$ & Dominansi (D) \\
\hline 1. & Hulu & 1,50 & 0,41 & 0,59 \\
\hline 2. & Tengah & 1,21 & 0,34 & 0,66 \\
\hline 3. & Hilir & 1,56 & 0,38 & 0,62 \\
\hline \multicolumn{2}{|r}{ Rata-rata } & 1,42 & 1,13 & 1,87 \\
\hline
\end{tabular}


JURNAL ILMIAH BIOSMART (JIBS)

Volume 1, Nomor 1

JIBS

https://jurnal.fkip.unmul.ac.id/index.php/biosmart

Tabel 5. Indeks Keanekaragaman, Keseragaman, dan Dominansi Zooplankton di Kelurahan Sungai Pinang Luar Kota Samarinda

\begin{tabular}{|c|c|c|c|c|}
\hline No & Stasiun Penelitian & $\begin{array}{c}\text { Indeks } \\
\text { Keanekaragaman } \\
\left(\mathrm{H}^{\prime}\right)\end{array}$ & $\begin{array}{c}\text { Indeks } \\
\text { Keseragaman (E) }\end{array}$ & Dominansi (D) \\
\hline 1. & Hulu & 1,21 & 0,34 & 0,65 \\
\hline 2. & Tengah & 1,28 & 0,37 & 0,66 \\
\hline 3. & Hilir & 1,46 & 0,37 & 0,62 \\
\hline \multicolumn{2}{|r|}{ Rata-rata } & 1,32 & 1,08 & 1,93 \\
\hline
\end{tabular}

\section{PEMBAHASAN}

Kualitas air merupakan suatu kondisi air secara kualitatif yang diukur dan diuji berdasarkan parameter-parameter tertentu, sehingga dari hasil pengukuran tersebut dapat diketahui bahwa air yang ada saat ini masih dalam kondisi baik sesuai dengan peruntukan perairan tersebut.

Perubahan suhu berpengaruh terhadap proses fisika, kimia dan biologi badan air. Hasil rata-rata pengukuran suhu selama 3 kali pengambilan data pada 3 stasiun penelitian menunjukan bahwa nilai suhu di perairan Kelurahan Sungai Pinang Luar Kota Samarinda berkisar antara $29^{\circ} \mathrm{C}-30^{\circ} \mathrm{C}$, sehingga masih dalam kondisi normal suatu lingkungan. Hal ini mengindikasikan bahwa suhu perairan Kelurahan Sungai Pinang Luar Kota Samarinda masih layak untuk kehidupan plankton. Dari hasil penelitian ini juga suhu diperairan ini yang didasarkan pada 3 stasiun penelitian menunjukan bahwa kualitas air berdasarkan parameter suhu masih dalam kondisi baik.

Muatan padatan tersuspensi (Total Suspended Solid atau TSS) adalah bahanbahan tersuspensi (diameter >1 $\mu \mathrm{m}$ ) yang bertahan pada saringan miliopore dengan diameter pori 0,45 $\mu \mathrm{m}$. TSS terdiri dari lumpur dan pasir halus serta jasad-jasad renik. Penyebab TSS di perairan yang utama adalah kikisan tanah atau erosi tanah yang terbawa ke badan air. Jumlah TSS pada perairan Kelurahan Sungai Pinang Luar Kota Samarinda pada stasiun 1 dan stasiun 2 memiliki nilai yang sama yaitu sebesar $45 \mathrm{mg} / \mathrm{L}$. Sedangkan batas standar baku mutu air yang ada di perairan karang mumus termasuk dalam baku mutu kelas II yaitu berkisar antara $50 \mathrm{mg} / \mathrm{L}$. Sehingga kualitas air di perairan ini masih 


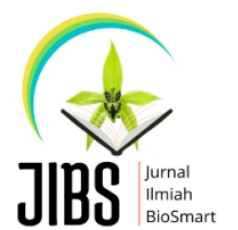

JURNAL ILMIAH BIOSMART (JIBS)

Volume 1, Nomor 1

https://jurnal.fkip.unmul.ac.id/index.php/biosmart

memenuhi standar baku mutu air kelas 2 yaitu bisa digunakan sebagai budidaya ikan air tawar, peternakan, pengairan tanaman peruntukan lain yang mempersyaratkan mutu air yang sama dengan kegunaan tersebut.

Derajat keasaman $(\mathrm{pH})$ adalah salah satu faktor yang mampu mempengaruhi laju fotosintesis. Proses fotosintesis oleh plankton akan berjalan secara optimal dengan $\mathrm{pH}$ dalam keadaan normal. Nilai derajat keasaman pada masing-masing stasiun di perairan Kelurahan Sungai Pinang Luar Kota Samarinda yaitu berkisar antara 6-6,55. Berdasarkan Peraturan Pemerintah NO. 82 Tahun 2001 tentang baku mutu kualitas air sungai, bahwa baku mutu yang baik atau optimal berkisar antara $\mathrm{pH}$ 6-9. Jadi pada stasiun 1 sampai dengan 3 masih dapat memenuhi baku mutu kualitas air sungai.

Berdasarkan hasil pengukuran DO di perairan Kelurahan Sungai Pinang Luar Kota Samarinda pada 3 stasiun penelitian dengan 3 kali pengulangan data diketahui bahwa nilai DO sangat bervariasi. Hasil tersebut kemudian dibandingkan dengan Peraturan Pemerintah Nomor 82 Tahun 2001, yang memiliki ambang batas DO > 4, maka hanya nilai DO sebesar 4,37 mg/L pada stasiun 1 yang sesuai dengan ambang batas yang telah ditentukan. Sedangkan nilai DO pada stasiun 2 dan di stasiun 3 memiliki nilai sebesar 1,78 $\mathrm{mg} / \mathrm{L}$ dan 0,98 mg/L, artinya nilai DO kurang dari ambang batas yang telah ditentukan, hal ini menunjukan bahwa kebutuhan oksigen terlarut untuk biota air yang hidup di lingkungan tersebut tidak dapat terpenuhi dengan baik.

COD atau kebutuhan oksigen kimia adalah salah satu parameter yang menentukan kualitas air berdasarkan jumlah oksigen yang diperlukan agar limbah organik yang ada di dalam air dapat teroksidasi melalui reaksi kimia. Berdasarkan hasil pengukuran di perairan Kelurahan Sungai Pinang Luar Kota Samarinda pada 3 stasiun penelitian dengan 3 kali pengulangan data diketahui bahwa nilai COD sangat bervariasi. Hasil pengukuran parameter kimia (COD) pada ketiga stasiun pengamatan yaitu sebesar $86,77 \mathrm{mg} / \mathrm{L}$ - 67,40 mg/L. berdasarkan data diatas nilai COD pada ketiga stasiun pengamatan tidak memenuhi standar baku mutu air sungai karang mumus kelas 2. Hasil ini menunjukan bahwa pada 3 stasiun ini terdapat jumlah cemaran limbah yang sangat 


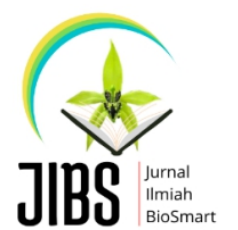

JURNAL ILMIAH BIOSMART (JIBS)

Volume 1, Nomor 1

https://jurnal.fkip.unmul.ac.id/index.php/biosmart

tinggi. Sehingga membuat reaksi kimia oksidasi yang ada diperairan tersebut sangat membutuhkan jumlah oksigen yang sangat besar untuk memecah partikel-partikel dari polutan atau limbah organik maupun anorganik.

BOD merupakan salah satu parameter untuk menentukan seberapa air sungai telah tercemar, khususnya pencemaran buangan bahan organik yang tidak mudah terurai. BOD menunjukan jumlah oksigen yang dikonsumsi oleh respirasi mikro aerob. Banyaknya oksigen yang diperlukan oleh bakteri untuk menguraikan polutan. Jika hasil pengukuran BOD dibandingkan dengan Peraturan Pemerintah Nomor 82 Tahun 2001 tentang baku mutu kualitas air sungai yaitu sebesar $3 \mathrm{mg} / \mathrm{L}$, maka kebutuhan oksigen diperairan Kelurahan Sungai Pinang Luar Kota Samarinda pada stasiun 1 sebesar 3,32 mg/L masih dalam kondisi baik. Sedangkan pada stasiun 2 sebesar $0,93 \mathrm{mg} / \mathrm{L}$ dan stasiun 3 sebesar 0,74 mg/L masih berada di bawah nilai ambang batas baku mutu perairan sungai karang mumus.

Plankton adalah organisme yang terapung atau melayang-layang di dalam air yang berperan penting dalam ekosistem perairan. Pergerakan dari plankton relative pasif, sehingga selalu terbawa ke dalam arus air. Selain itu plankton juga sangat merepson perubahan kondisi perairan, sehingga plankton dapat dijadikan sebagai bioindikator suatu perairan.

ditemukan 9 jenis fitoplankton yang termasuk ke dalam 7 kelas. 9 jenis fitoplankton ini meliputi: Tabellaria sp, Ulothrix sp, Oscillatoria sp, Spirulina sp, Amphidinium pseudomassarti, Closterium sp, Naviculla sp, Surrirella elegansi, Chlamydomonas sp serta ada 6 jenis zooplankton yang termasuk dalam 5 kelas 6 jenis zooplankton in meliputi: Phacus sp, Trachelomonas sp, Euglena viridis, Arcella vulgaris, Filinia Longsiseta, dan Centropxis sp. Dari plankton yang ditemukan anggota kelas Bacillariopyceae dan kelas Cyanophyceae yang umumnya digunakan sebagai bioindikator diperairan.

Plankton dari kelas Bacillariophyceae adalah yang paling banyak ditemukan, dari pernyataan ini sesuai dengan pendapat Syadiah (2002: 67) bahwa dari kelas 


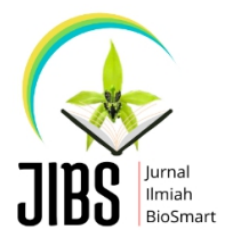

JURNAL ILMIAH BIOSMART (JIBS)

Volume 1, Nomor 1

https://jurnal.fkip.unmul.ac.id/index.php/biosmart

Bacillariophyceae inilah yang lebih mendominan dari pada kelas lainnya dikarenakan kelas Bacillariophyceae lebih mudah beradaptasi pada lingkungan perairan yang mengalami penurunan.

Seperti yang telah diketahui, bahwa anggota dari Bacillariophyceae dan Cyanophyceae bisa dijadikan bioindikator pencemaran perairan. Oscillatoria diketahui memiliki kemampuan bertahan terhadap perubahan kondisi lingkungan yang tidak menguntungkan. Hal ini dimungkinkan Oscillatoria memiliki sel pembungkus yang berlapis. Kondisi inilah yang diduga mampu membuat Oscillatoria bertahan hidup dengan kondisi lingkungan perairan yang tercemar.

Kelas Chlorophyceae juga ditemukan di Perairan Kelurahan Sungai Pinang Luar kota Samarinda. Chlorophyceae merupakan organisme prokariyotik, yang memiliki kloroplas tipe klorofil a dan b, memiliki pigmen tambahan berupa karotin, komponen dinding selnya adalah selulosa. Kemudian genus Ulothrix yang berasal dari sampel air, genus ini merupakan mikroalga, Ulothrix $s p$ dari kelas Chlorophyceae memiliki karakteristik morfologi secara umum bersifat uniseluler.

Divisi Euglenophtya merupakan organisme bersel tunggal dengan susunan sel eukarota. Spesies yang ditemukan yaitu Euglena sp, dan Trachelomonas sp, pada dasarnya euglena memiliki dua buah flagel tipe cambuk berjumbai dengan tonjolan lateral yang berupa bulu yang terletak pada satu barisan sepanjang flagel. Sedangkan menurut anggota dari Bacillariophyceae digunakan sebagai bioindikator pencemaran air karena memiliki dinding sel yang terbuat dari silica. Dinding sel yang terbuat dari silica pada umumnya kuat atau masih tetap utuh. Selain itu, Bacillariophyceae mempunyai peranan yang penting di dalam proses mineralisasi dan proses daur ulang bahan-bahan organik, baik yang berasal dari perairan maupun daratan. 


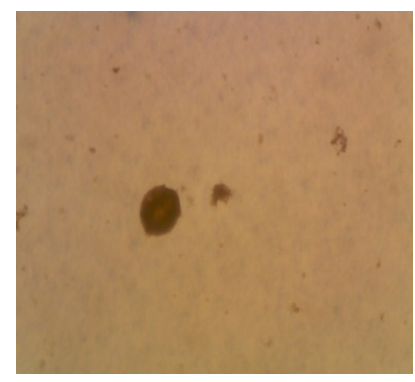

a.

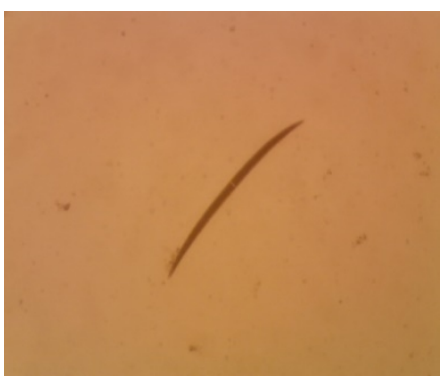

b.

Gambar 5. Jenis Plankton Amphidinium pseudomassarti dan Closterium sp

\section{KESIMPULAN}

Berdasarkan penelitian dan analisis data yang telah dilakukan maka dapat disimpulkan bahwa:

Kualitas air di perairan Kelurahan Sungai Pinang Luar Kota Samarinda ditinjau berdasarkan parameter plankton sebagai bioindikator berada dalam kondisi tercemar yang sedang karena adanya plankton dari kelas Bacillariophyta, Chlorophyceae, Cyanophyceae. Penentuan ini didasarkan pada data hasil pengukuran yang dibandingkan dengan keputusan Peraturan Pemerintah Nomor 82 Tahun 2001 tentang Pengelolaan Kualitas Air dan Pengendalian Pencemaran Air.

\section{DAFTAR RUJUKAN}

Ernawaty., Sitti. S dan Rabanai. 2011. Komposisi Jenis Zooplankton di Perairan Sungai Je'neberang Sungguminasa Kec. Somba Opu Kab. Gowa. Jurnal Bionature. 12(1). https://ojs.unm.ac.id/bionature/article/view/1393 (diakses pada tanggal 14 September 2020).

Junda. M., Hasrah dan Yusminah. H. 2012. Identifikasi Genus Fitoplankton pada Salah Satu Tambak Udang di Desa Bontomate'ne Kecamatan Segeri Kabupaten Pangkep. Jurnal et.al., identifikasi Genus Fitoplankton pada Salah Satu Tambak

Udang di Desa Bontomate'ne. 13(2). 


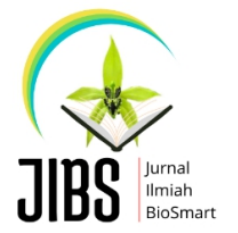

JURNAL ILMIAH BIOSMART (JIBS)

Volume 1, Nomor 1

https://jurnal.fkip.unmul.ac.id/index.php/biosmart

https://ojs.unm.ac.id/bionature/article/view/1435 (diakses pada tanggal 14 September 2020)

Peraturan Pemerintah Republik Indonesia Nomor 82. 2001. Pengelolaan Kualitas Air dan Pengendalian Pencemaran Air.

Syadiah, Nurfitri. 2002. Struktur Komunitas Fitoplankton di Teluk Lampung Pada Bulan Juli, September, dan November 2001. Skripsi. Bogor: Fakultas Perikanan dan Perikanan Institut Pertanian Bogor

Warsilan. 2019. Dampak Perubahan Guna Lahan Terhadap Kemampuan Resapan Air (Kasus: Kota Samarinda). Jurnal Pembangunan Wilayah dan Kota. Vol 1 No. 1. https://ejournal.undip.ac.id/index.php/pwk/article/view/20713 (diakses pada tanggal 15 Januari 2020) 